\title{
VOEDINGSFYSIOLOGISCH ONDERZOEK IN SURINAME
}

In een artikel over voedingsonderzoek op de Bovenwindse Eilanden, werden in De West-Indische Gids van I958 enige algemene aspecten en doelstellingen van voedingsonderzoek besproken. Dank zij een subsidie van de Stichting Wetenschappelijk Onderzoek Suriname - Nederlandse Antillen (WOSUNA), konden schrijver en zijn echtgenote in I958-I959 enkele speciale voedingsproblemen in Suriname nader bestuderen. Dit onderzoek was mede een aanvulling op het menu-onderzoek dat onder leiding van Dr. E. vAN DER KUYP bij verschillende Surinaamse bevolkingsgroepen had plaatsgevonden.

Het onderzoek had o.a. tot doel:

a. nadere gegevens te verzamelen over de voedingsnormen die in Suriname toegepast moeten worden;

b. na te gaan of uit Surinaamse produkten een goede voeding samengesteld kan worden;

c. Gegevens te verzamelen over de lichaamsmaten van Surinamers (z.g. somatometrische gegevens).

Ad $a$. - Zoals destijds werd opgemerkt, worden in de tropen gewoonlijk de voedingsnormen toegepast die verkregen zijn door onderzoek bij Noord-Amerikanen of Europeanen, welke normen gebaseerd zijn op de specifieke voedingsgewoonte uit deze landen. Het is echter veel logischer in tropische landen normen te gebruiken, die gebaseerd zijn op de eigenschappen van de mensen uit deze landen en op de eigenschappen van hun eigen voedingsmiddelen. Wij kennen twee soorten normen: de (minimale) behoefte die beslist nodig is om gezond te blijven, en de 'aanbevolen hoeveelheden' die uit veiligheidsoverwegingen veel hoger gesteld worden dan de behoefte.

Gegevens over de normen werden bij dit onderzoek op twee manieren verkregen:

I. Door te zoeken naar deficiëntieverschijnselen bij bevolkingsgroepen waarvan de voeding bekend is. Komen er verschijnselen van een tekort aan een bepaalde voedingsstof (nutriënt) voor, dan moet de voeding te weinig van deze stof bevatten of, wat hetzelfde resultaat geeft, het 
VOEDINGSFYSIOLOGISCH ONDERZOEK IN SURINAME IOI

lichaam houdt, onder de heersende omstandigheden, te weinig van deze stof vast. De behoefte moet dan in ieder geval hoger gesteld worden dan de hoeveelheid die in de voeding aanwezig was. Vinden wij daarentegen bij een bevolkingsgroep bepaalde deficiëntieverschijnselen niet, dan bevat hun voeding in ieder geval voldoende of meer dan voldoende van de betreffende nutriënten.

2. Verder werden zogenaamde stikstof-en calcium-balansstudies met specifiek Surinaamse voedingsmiddelen verricht. Uit deze balansstudies blijkt hoeveel stikstof en calcium het lichaam werkelijk weet vast te houden uit de betreffende voeding. Wij weten hoeveel stikstof en calcium in het lichaam moet worden vastgehouden, opdat het lichaam zich normaal kan ontwikkelen. De hoeveelheden die het lichaam uit de voeding vasthoudt, kunnen vaak heel sterk afwijken van de hoeveelheden die in de voeding aanwezig zijn. Zo houdt een gezond Amerikaans kind maar $30 \%$ van het calcium uit de voeding vast. De rest verlaat met de ontlasting het lichaam (MACY). De hoeveelheid ijzer die door het darmkanaal van gezonden geresorbeerd wordt, varieert van $\mathbf{I}-\mathbf{1 0} \%$ van de hoeveelheid die in de voeding aanwezig is (Hussein \& PATHWARDHAN). Het is speciaal deze door het lichaam vastgehouden hoeveelheid die het lichaam, de ontwikkeling en de gezondheid ten goede komt. Omdat deze vastgehouden hoeveelheid zo moeilijk te onderzoeken is, volstaat men gewoonlijk met analyses van de voeding.

Ad $b$. - Met deze methode van balansstudies werd vooral ook het probleem bestudeerd of uit Surinaamse voedingsmiddelen een goede voeding kan worden samengesteld. Daarom was het nodig een aantal Surinaamse voedingsmiddelen te analyseren.

Ad c. - De somatometrische gegevens werden om twee redenen verzameld. In de eerste plaats kunnen sterk afwijkende somatometrische gegevens op deficiẻnties wijzen. In de tweede plaats dienen zij als basis voor het berekenen van de voedingsnormen.

Dit onderzoek werd voorlopig beperkt tot de Bosnegers en de Javanen, terwijl op verzoek van de Regering ook een kleine groep Indianen onderzocht werd.

Aangezien er zeer veel chemische analyses verricht moesten worden, werden achtereenvolgens laboratoria ingericht in het Prinses Juliana Zendingshospitaal te Kabel, in het ziekenhuis van de Nederlandsche Handelmaatschappij te Mariënburg, in het hospitaal van de Suralco te Moengo en in het ziekenhuis te Albina. De analyses die niet ter plaatse uitgevoerd konden worden, werden verricht in het Laboratorium van het Landshospitaal (Dr. E. Li Fo SJoE) te Paramaribo, in het Laboratorium voor Chemische Physiologie der Vrije Universiteit van Amsterdam (Prof. Dr. H. K. Oosterhuis) en in het Centraal Instituut voor Voedingsonderzoek T.N.O. te Utrecht.

De gedetailleerde resultaten van deze onderzoekingen zijn vastgelegd in een negental artikelen in Tropical and geographical Medicine van 1960 en $196 \mathrm{I}$. 
I. DE DEFICIËNTIEVERSCHIJNSELEN

Door de plaatselijke artsen zijn bij de Bosnegerbevolking klinische verschijnselen van eiwit- en riboflavine-deficiëntie en bloedarmoede geconstateerd.

\section{Eireitdeficiëntie}

De verschijnselen van eiwitdeficiëntie worden uitsluitend bij jonge kinderen, en dan nog slechts incidenteel, waargenomen. $\mathrm{Zij}$ treden bovendien pas op wanneer het tekort zeer ernstig geworden is. Het leek ons daarom van belang met fijnere methoden, i.c. biochemisch onderzoek, naar eiwitdeficiëntieverschijnselen te zoeken.

In tabel I zijn enkele resultaten van deze bepalingen vermeld. Het albuminegehalte van het bloedserum is bij Bosnegers lager dan bij Europeanen. Dit was bij Javanen en Indianen niet het geval. Dit kàn een aanwijzing voor eiwittekort zijn, hoewel de eiwitbehoefte ook door infecties beïnvloed wordt. Anderzijds is het eiwittekort niet zo ernstig. Bij ernstig eiwittekort namelijk wordt ook het totaal eiwitgehalte lager dan bij Europeanen.

Het $\gamma$-globulinegehalte is bij alle groepen hoger dan bij Europeanen. Hoogstwaarschijnlijk spelen hierbij alleen infecties een rol zoals malaria, framboesia, geïnfecteerde huidaandoeningen, misschien ook infestaties van darmparasieten. De choline-esterase-activiteit van het bloedserum van Bosnegers is lager dan bij de andere groepen. Ook dit kan een gevolg van eiwittekort zijn.

De ureumuitscheiding in de urine van schoolkinderen was het hoogste bij kinderen op een Europees dieet, lager bij de Indianen, nog lager bij de Javanen van Mariënburg en het laagst bij de Bosnegers. De cijfers voor Javanen uit Moengo lagen gunstiger dan voor die uit Mariënburg, namelijk: ureum, percent totaal stikstof: 85 en ureum, gram per gram kreatinine: I8.8 Lage cijfers wijzen ook hier op een minder eiwitvoorziening. Bij de goede beoordeling van deze cijfers moet wel met een ruime spreiding rekening worden gehouden, zodat eigenlijk alleen de waarden gevonden bij de Bosnegers op een eiwittekort zouden kunnen wijzen.

Hoewel de activiteit van de enzymen amylase en lipase van het serum bij duidelijk eiwittekort verlaagd kan zijn, wijzen de resultaten van dit onderzoek ook op andere invloeden. De amylase-activiteit was bij de groep met de laagste eiwitvoorziening, de Bosnegergroep, namelijk niet lager maar juist hoger dan bij 
Europeanen. De voeding van de Bosnegers bevat naar verhouding veel meer koolhydraten dan die van Europeanen. Wij vragen ons af of een verklaring voor de grote activiteit aan koolhydraat-splitsend enzym misschien in de koolhydraatrijkdom van het dieet gezocht moet worden. Evenzo zou de vetarmoede van het dieet de lage lipase-activiteit bij de Bosnegers kunnen verklaren.

Uit het bovenstaande volgt dat de voeding van de Bosnegers tijdens het onderzoek niet voldoende eiwit bevatte om normale biochemische waarden in bloed en urine te handhaven. Hieruit kan geconcludeerd worden dat de eiwitbehoefte voor deze groep hoger ligt dan het gehalte hieraan in hun voeding thans bedraagt. Ook is het mogelijk dat wel de hoeveelheid eiwit voldoende is, doch dat de kwaliteit van dit eiwit slecht is.

\section{I! zerdeficiëntie}

Bloedarmoede is dikwijls een gevolg van ijzertekort. Maar ook eiwittekort, tekorten aan diverse vitamines of andere mineralen dan ijzer kunnen bloedarmoede veroorzaken. Treden infectieziekten op die met bloedverlies gepaard gaan, dan is meer ijzer nodig dan wanneer deze ziekten niet aanwezig zijn (WHITE c.s.).

Wij hebben met betrekkelijk nieuwe methoden naar mogelijke ijzertekorten gezocht (VERLOOP c.s.). Het bleek hierbij (tabel 2) dat het ijzergehalte in het serum bij Bosnegers lager was dan bij Javanen. De zogenaamde latente ijzerbindende capaciteit was juist hoger, evenals de 2-uurs-stijging, d.i. de stijging van het ijzergehalte van het serum twee uur nà het innemen van een bepaalde hoeveelheid ijzer in drankvorm. Bij de Indianen en de Javanen lagen alle waarden op Europees niveau.

De huidige voeding van de Bosnegers bevat dus niet voldoende ijzer om normale waarden in het serum te handhaven. Ongetwijfeld vormen de verschillende infecties en infestaties van parasieten een extra-belasting van de ijzerstofwisseling.

\section{Calciumdeficiëntie}

Voor Amerikaanse en West-Europese kinderen wordt $1000 \mathrm{mg}$ calcium per dag aanbevolen. In vele tropische streken bevat de voeding per dag niet meer dan enkele honderden milligrammen calcium. Toch zien de artsen in die streken zelden opvallende klinische verschijnselen van calciumgebrek. Wij hebben met vier verschillende, meer verfijnde methoden naar mogelijke verschijn- 
TABEL I. Resultaten van het biochemisch onderzoek van bloed en urine van enkele bevolkingsgroepen

\begin{tabular}{|c|c|c|c|c|}
\hline & Bosnegers & Javanen & Indianen & Europeanen \\
\hline \multicolumn{5}{|l|}{$\begin{array}{l}\text { Gehalte, resp. activiteit bloed- } \\
\text { serum van volwassenen aan: }\end{array}$} \\
\hline Albumine $\quad: \quad \mathrm{g} / 100 \mathrm{ml}$ & $4.2 \pm 0.4$ & $4.6 \pm 0.6$ & $4.6 \pm 0.5$ & $4.5 \pm 0.3$ \\
\hline$\gamma$ Globuline $: \mathrm{g} / \mathrm{I00} \mathrm{ml}$ & $1.7 \pm 0.4$ & $1.5 \pm 0.4$ & $1.6 \pm 0.3$ & $0.9 \pm 0.2$ \\
\hline Totaal eiwit: $\mathrm{g} / \mathrm{roo} \mathrm{ml}$ & $7.4 \pm 0.6$ & $7.5 \pm 0.6$ & $7.9 \pm 0.7$ & $6.7 \pm 0.4$ \\
\hline Cholesterol : mg/100 ml & $\begin{array}{l}\text { ơ } \mathbf{1 2} \pm 3 \mathbf{1} \\
\text { } \mathbf{1} 55 \pm 35\end{array}$ & $\begin{array}{l}\text { ơ } 164 \pm 34 \\
\text { ○ } 202 \pm 39\end{array}$ & $151 \pm 27$ & $\begin{array}{l}\text { ô } 221 \pm 46 \\
\text { o } 220 \pm 22\end{array}$ \\
\hline Amylase-activiteit & I $54 \pm 44$ & $152 \pm 35$ & - & $110 \pm 23$ \\
\hline Lipase-activiteit & $15^{8} \pm 29$ & $207 \pm 39$ & $200 \pm 25$ & $195 \pm 4 I$ \\
\hline Cholineësterase-activiteit & o $85 \pm 18$ & $0112 \pm 27$ & - & - \\
\hline $\begin{array}{l}\text { (in \% van 'normale' waarden) } \\
\text { Aantal onderzochte personen }\end{array}$ & $\begin{array}{c}\text { 우 } 80 \pm 14 \\
109\end{array}$ & 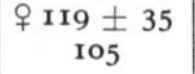 & $\overline{33}$ & - \\
\hline \multicolumn{5}{|l|}{$\begin{array}{l}\text { Gehalte urine van schoolkinderen } \\
\text { aan: } \\
\text { Ureumstikstof in } \% \text { van }\end{array}$} \\
\hline $\begin{array}{l}\text { totaal stikstof } \\
\text { Ureum in } \mathrm{g} \text { per } \mathrm{g} \text { kreatinine }\end{array}$ & $53 \pm 17$ & $\begin{aligned} 79 & \pm 9 \\
& +5.0\end{aligned}$ & $80 \pm 14$ & $87 \pm 9$ \\
\hline $\begin{array}{l}\text { Ureum in } g \text { per } g \text { kreatinine } \\
\text { Aantal onderzochte personen }\end{array}$ & $\begin{array}{c}7 \cdot 5 \pm 4.0 \\
32\end{array}$ & $\begin{array}{c}13.7 \pm 5.0 \\
60\end{array}$ & $\begin{array}{c}17.8 \pm 6.1 \\
80\end{array}$ & $\begin{array}{c}28.0 \pm 8 \\
15\end{array}$ \\
\hline
\end{tabular}

TABEL 2. Gegevens over de ijzerstofwisseling

\begin{tabular}{|c|c|c|c|}
\hline & Bosnegers & Javanen & Indianen \\
\hline Haemoglobine $\quad \mathrm{g} / \mathrm{roo} \mathrm{ml}$ & $\mathbf{r} 2.4 \pm \mathbf{r} .8$ & $\mathrm{r} 3.4 \pm \mathrm{I} .4$ & - \\
\hline $\begin{array}{l}\text { IJzergehalte bloedserum } \quad \mu \mathrm{g} / \text { roo ml } \\
\text { Latente ijzerbindende ca- }\end{array}$ & $62 \pm 28$ & $110 \pm 4^{\circ}$ & $85 \pm 29$ \\
\hline paciteit van bloedserum $\mu \mathrm{g} / \mathrm{IOO} \mathrm{ml}$ & $213 \pm 71$ & $18 r \pm 63$ & - \\
\hline $\begin{array}{l}\text { 2-uurs-stijging in bloed- } \% \\
\text { serum }\end{array}$ & $166 \pm 7^{2}$ & $65 \pm 57$ & - \\
\hline Aantal onderzochte personen & 14 & 24 & 33 \\
\hline
\end{tabular}

selen van calciumgebrek gezocht. De resultaten waren niet eensluidend.

De zogenaamde skeletleeftijd, d.i. de mate van verkalking van het skelet, werd bepaald op röntgenfoto's van de hand van schoolkinderen. Deze skeletleeftijd was één tot twee jaar achter bij die van Amerikaanse kinderen van dezelfde leeftijd. Opgemerkt zij, dat de verkalking van het skelet niet alleen door voedsel-calcium beïnvloed wordt; ook het eiwitgehalte van de voeding speelt hierbij een rol. Merkwaardigerwijze was er geen 
duidelijk verschil in skeletleeftijd tussen de kinderen uit Moengo enerzijds en de kinderen uit de andere groepen anderzijds. Wij hadden verwacht dat de skeletleeftijd in Moengo hoger zou liggen, omdat daar het gebruik van melk, die veel calcium bevat, gestimuleerd wordt. Misschien heeft deze melkverstrekking nog te kort geduurd. Het zou daarom interessant zijn over enkele jaren dit onderzoek te herhalen.

Het calcium- en fosforgehalte en de fosfatase-activiteit van het bloedserum van een aantal Javaanse kinderen lag op een normaal niveau.

De hoeveelheid calcium uitgescheiden in de urine ná intraveneuze inspuiting van calciumgluconaat was bij $4 \mathrm{I}$ volwassen personen normaal en wees niet op een calciumtekort.

De moedermelk van I6 zogende Bosnegervrouwen bevatte $22.8 \mathrm{mg}$ calcium per Ioo $\mathrm{ml}$ terwijl melk van Nederlandse vrouwen $28.0 \mathrm{mg}$ per $100 \mathrm{ml}$ bevat.

Twee van de vier methoden gaven uitkomsten die op een calciumtekort zouden kunnen wijzen, namelijk de bepaling van de skeletleeftijd en de bepaling van het calciumgehalte in de moedermelk. De twee andere methoden, de analyse van bloedserum op calcium, fosfor en fosfatase-activiteit, en de bepaling van calciumuitscheiding na intraveneuze calciumbelasting, wezen daar niet op. In verband met deze elkaar tegensprekende resultaten verdient het aanbeveling het onderzoek naar de calciumdeficiëntie in Suriname voort te zetten resp. uit te breiden.

\section{Balansstudies}

In Noord-Amerika en Europa wordt aanbevolen dat een goede voeding 70-I00 $\mathrm{g}$ eiwit bevat, waarvan 50 à $30 \%$ dierlijk eiwit moet zijn. Daar staat tegenover dat in tropische streken veel minder eiwit wordt gebruikt, dikwijls nagenoeg geheel van plantaardige oorsprong. Wij weten nu dat de voedingswaarde van een eiwit bepaald wordt door de kwaliteit van het eiwit. De kwaliteit van de meeste plantaardige eiwitten is slechter dan van dierlijke. Er zijn echter combinaties van plantaardige eiwitten die even goed zijn als dierlijke. Wij weten dit al sedert de proeven van JanSEN \& Donath in 1924.

De eiwitten in de voeding van de door ons bestudeerde bevolkingsgroepen zijn grotendeels plantaardig. Bovendien bevat deze voeding weinig calcium. Om uit te maken hoe de kwaliteit van het eiwit is en of de kleine hoeveelheid calcium misschien 
toch nog goed benut kan worden hebben wij balansstudies verricht. Deze balansstudies vragen veel werk en organisatie. Gedurende een aantal dagen, liefst weken, moeten de proefpersonen precies afgewogen hoeveelheden eten en drinken krijgen. Deze voeding moet op stikstof (eiwit) en calcium geanalyseerd worden. Gedurende de gehele periode moet alle urine en alle ontlasting worden opgevangen en eveneens worden geanalyseerd.

Deze balansproeven werden bij 7 Bosnegerkinderen en II Javaanse kinderen van 4 tot II jaar verricht. De Bosnegerkinderen kregen het volgende dieet: 's morgens en 's avonds cassavebrood met een klein beetje vis of pindakaas. 's Middags kregen ze rijst met een kleine hoeveelheid groenten en vis of vlees. Deze voeding leverde $4.6 \mathrm{~g}$ stikstof, d.i. ongeveer $29 \mathrm{~g}$ eiwit, waarvan slechts $3.8 \mathrm{~g}$ dierlijk eiwit. Toch hielden de kinderen $0.82 \mathrm{~g}$ stikstof per dag vast, dus meer dan voldoende. Amerikaanse kinderen houden namelijk op een dieet dat drie maal meer eiwit bevat, waarvan $60 \%$ van dierlijke oorsprong, evenveel stikstof vast.

De Javaanse kinderen kregen 's morgens brood met boter en jam en 's middags en 's avonds rijst met groente en vis. Bij enkele van hen werd later vis vervangen door waterpap van gemalen sojabonen. Dit dieet bevatte $6.2 \mathrm{~g}$ stikstof, d.i. $39 \mathrm{~g}$ eiwit, waarvan $4.4 \mathrm{~g}$ dierlijk. Zij hielden zelfs I.26 g stikstof vast.

Uit deze proeven blijkt dat deze kinderen evenveel of meer stikst of vasthouden dan Amerikaanse kinderen op een dieet met veel meer eiwit. De Amerikaanse kinderen 'verspillen' dus veel meer stikst of (eiwit). Ook bleek dat het vervangen van vis door gemalen sojapap geen enkele duidelijke verandering in de balans veroorzaakte.

De hierboven gegeven hoeveelheden eiwit mogen dus zeker als voldoende beschouwd worden.

Voor calcium lagen de resultaten iets anders. De voeding van de Bosnegerkinderen leverde $207 \mathrm{mg}$ per dag. Zij hielden gemiddeld $36 \mathrm{mg}$ calcium per dag vast. Drie van de zeven Bosnegerkinderen hielden voor hun leeftijd voldoende calcium vast, evenals zes van de elf Javaanse kinderen. Gemiddeld werd via het darmkanaal 40-60\% van het voedselcalcium door het lichaam opgenomen. Bij Amerikaanse kinderen is dit maar ca 30\%. Ook aan calcium verspillen deze Amerikaanse kinderen dus meer.

Aangezien een deel van de kinderen niet voldoende calcium vasthielden, zouden de balansproeven herhaald moeten worden met grotere hoeveelheden calcium. 


\section{SOMATOMETRISCH ONDERZOEK}

Er werden 655 Bosnegers, 432 Javanen uit het Commewijnedistrict en Lelydorp, I39 Javanen uit Moengo en I40 Indianen gemeten. Wij maten lengte en gewicht en enkele omtrek-maten die een indruk moeten geven van de spiermassa, alsmede het onderhuidse vet op een aantal plaatsen van het lichaam.

In de eerste plaats trachtten wij uit deze maten af te leiden of er deficiënties bestonden. De Bosnegermannen waren $13 \mathrm{~cm}$ korter en ro kg lichter dan mannen van de Bovenwindse Eilanden van de Nederlandse Antillen (LUYKen \& LUYKen-Koning) die van dezelfde oorsprong zouden zijn. Zesjarige kinderen waren $9 \mathrm{~cm}$ korter en $2 \mathrm{~kg}$ lichter en de negenjarigen ro $\mathrm{cm}$ korter en 3 $\mathrm{kg}$ lichter dan de Antillianen. Het is best mogelijk dat dit grote verschil door slechtere voeding in vroegere tijden veroorzaakt is. De hoeveelheid spiermassa van de Bosnegers was echter beslist niet minder en dit wijst er op, dat althans op grond van dit criterium de voeding in de laatste tijd niet zoveel slechter was dan van de Antillianen. Op grond van andere criteria moet de voeding wel als onvoldoende gekwalificeerd worden, zoals in het voorgaande betoogd werd. De Bosnegers hadden minder onderhuids vet dan de Antillianen.

De Javanen werden vergeleken met goed gevoede Javanen, vóór de oorlog op Java gemeten. De Surinaamse Javanen waren even lang, doch zwaarder dan de goed gevoede Javanen van Java. Vooral de vrouwen hadden opvallend veel onderhuids vet. Dit is niet altijd gunstig. Een té grote hoeveelheid onderhuids vet is schadelijk voor de gezondheid. Wij zullen bij de bespreking van het cholesterolgehalte van het bloedserum zien dat er aanwijzingen zijn dat de hoeveelheid onderhuids vet van deze vrouwen als minder gunstig beschouwd moeten worden.

\section{Cholesterolgehalte van het bloedserum}

Dit cholesterolgehalte werd onderzocht in verband met het zeer belangrijke atherosclerose-vraagstuk. Atherosclerose (aderverkalking) neemt in West-Europa en Noord-Amerika onrustbarend toe (GROEN c.s.). Een zeer belangrijke complicatie hiervan is de plotselinge afsluiting van een groot bloedvat van het hart, wat dikwijls tot plotselinge dood aanleiding geeft. Er zijn allerlei aanwijzingen dat, naast psychische spanningen, ook overmatige voeding of de grote hoeveelheid vet in de voeding, en dan waar- 
schijnlijk speciaal het dierlijk vet, deze aandoening bevorderen. Ook het gebrek aan lichaamsbeweging zou van invloed kunnen zijn (GRoen c.s.). Andere onderzoekers zien ook verband met de hoeveelheid of de kwaliteit van het eiwit (DE GROOT). Door vele onderzoekers, doch lang niet door alle, wordt een hoog cholesterolgehalte van het bloed beschouwd als een aanwijzing voor het aanwezig zijn of voor het mogelijke ontstaan van deze atherosclerose.

In de tropen is deze vorm van atherosclerose bij sectie zelden gevonden. Het cholesterolgehalte is bij deze mensen laag. Wordt hun voeding meer westers, dan stijgt het cholesterolgehalte en vermoedelijk ook de frequentie van atherosclerose.

In Suriname konden we dit alles bevestigen. De Bosnegers met hun primitieve voeding hadden het laagste cholesterolgehalte (I42-I44 mg/roo ml). Bij de Javaanse mannen was het nauwelijks hoger, namelijk $\mathrm{I} 64 \mathrm{mg} / \mathrm{IOO} \mathrm{ml}$. Bij de Javaanse vrouwen, die minder lichaamsbeweging hebben maar toch zeer overvloedig eten, getuige hun dikke onderhuidse vetlagen, stijgt het cholesterolgehalte aanzienlijk, namelijk tot $202 \mathrm{mg} / \mathrm{Ioo} \mathrm{ml}$. Bij de in Suriname onderzochte, meestal jonge, Europeanen was het gehalte $220 \mathrm{mg} / \mathrm{IO0} \mathrm{ml}$.

Het zou van groot belang zijn na te gaan of het vóórkomen van aderverkalking en speciaal hartcomplicaties bij deze groepen verband houdt met het cholesterolgehalte.

5. Samenstelling van enkele Surinaamse levensmiddelen In het kader van dit onderzoek hebben wij een aantal Surinaamse levensmiddelen meer of minder volledig geanalyseerd. Het voert o.i. te ver om de resultaten hier gedetailleerd weer te geven. Het betreft de volgende produkten: geelgekleurde cassave, cassave-brood, napi (Dioscorea trifida), yam (Dioscorea alata), tajer (Xanthosoma sagittifolium), switie boontjes (Inga ingoïdes), awarra (Astrocaryum segregatum), maripa (Maximiliana maripa), paramakka (Astrocaryum paramaca) en koemboe (Oenocaryum batava).

\section{Prijs van LeVensmiddelen}

Wij hebben op grond van de marktprijzen te Paramaribo in april-mei 1959 berekend hoeveel een gram van een van de belangrijkste nutriënten, namelijk goed eiwit, uit een aantal Surinaamse levensmiddelen kostte. In het volgende lijstje is de prijs in centen van een gram eiwit uit het betreffende produkt vermeld: 

gedroogde geschubde vis 1.2 gedroogde, niet-geschubde vis 0.4 $\begin{array}{lll}\text { vlees } & \text { I.I peulvruchten } & 0.3\end{array}$ melk I.o trassie 0.2

De levensmiddelen die de goedkoopste eiwitten bevatten zijn voor de Surinaamse volksvoeding uit de aard der zaak van groter belang dan die waarvan de eiwitten duurder zijn.

\section{LITERATUUR}

Groen, J. \& Heide, R. M. van der: Atherosclerose en voeding. Voeding I7, 1956, p. 485-500, 526-548.

GRoot, A. P. DE: De invloed van eiwitten en andere nutriënten op de cholesterolspiegel van het bloed. Voeding 21 , 1960, p. 374-386.

Hussein, R. \& Pathwardhan, V. N.: The influence of phytate on the absorption of iron. Ind. J. med. Res. 47, 1959, p. 676-682.

Jansen, B. C. P. \& Donath, W. F.: Over het gehalte aan A-vitamine van verschillende Indische voedingsmiddelen en over de waarde van de eiwitten ervan als aanvulling der rijsteiwitten. Meded. Dienst Volksgezondheid 5, 1924, p. 48-102.

LUYKEN, R.: Over voedingsproblemen in de tropen in verband met het voedingsonderzoek op de Bovenwindse Eilanden. W. I. Gids 38, 1958, p. 86-96.

LUYKen, R. \& LUyKen-Koning, F. W. M.: Nutrition research in the Windward Islands (Netherlands Antilles) II. Medical examination of the population. Trop. geogr. Med. II, 1959, p. I03-II4.

MACY, I. G.: Nutrition and chemical growth in childhood. Vol. I., $194^{2}$ (p. I6I).

Verloop, M. C. \& Meeuwissen, J. E. H. Ph. \& Blokhuis, E. W. M.: Vergelijking van de 'ijzerbelastingscurve' met de ijzerbindingscapaciteit van het serum bij het stellen van de diagnose ijzergebrek. Ned. Tijdschr. Geneesk. 102, 1958, p. 1877-1880.

White, R. P. C. S. : Effects of iron treatment of anemia in a tropical area. Am. J. Clin. Nutr. 5, 1957, p. 621-628.

\section{SUMMARY}

\section{Research into Nutritional Physiology in SuRinam}

In $195^{8}$ and 1959, the author and his wife carried out researches into nutritional physiology in Surinam, the objects of which included: $a$, collection of further details regarding the standards of nutrition which must be applied in Surinam; $b$, investigation of whether a good diet can be composed from Surinam products; $c$, collection of data regarding the body measurements of Surinamese (somatometric data). Researches 
were provisionally restricted to the Bush Negroes and Javanese, though a small group of Indians was also investigated at the request of the Governemnt.

It was found that the diet of the Bush Negroes during the investigation did not contain sufficient protein to maintain normal biochemical values in the blood and urine. From this it can be concluded that this group's protein requirements are higher than the content of protein in their present diet. It is likewise possible that the quantity of protein is sufficient but that its quality is poor. Infections and infestations by parasites probably also play a part.

Furthermore, the present diet of the Bush Negroes proved not to contain enough iron to maintain normal values in the blood serum. The various infections and infestations by parasites undoubtedly impose an extra burden on the iron metabolism.

Four different methods were applied in order to detect symptoms of calcium deficiency. Results which might indicate such deficiency were obtained by only two of the four methods (viz., determination of the age of the skeleton and determination of the calcium content of breast milk). In connection with these inconclusive results, it would be advisable to continue or extend investigations into calcium deficiency in Surinam.

In nitrogen balance studies, tests carried out on seven Bush Negro children and eleven Javanese children showed that they retain as much nitrogen as or more nitrogen than American children on a diet containing far more protein. The results of the calcium balance studies were less clear.

Somatometric investigations among Bush Negroes, Javanese and Indians showed that Bush Negro men were $13 \mathrm{~cm}$ shorter and $10 \mathrm{~kg}$ lighter than men of the Windward Group islands of the Netherlands Antilles, who likewise presumably originated from Africa. However, in the Bush Negroes the quantity of muscle tissue was not less, which was the case as regards subcutaneous fat. The Javanese, who were compared with well-nourished Javanese measured in Java before the war, were just as tall as the latter, but heavier.

The cholesterol content of the blood serum was investigated in connection with the question of atherosclerosis. The Bush Negroes, with their primitive diet, had the lowest cholesterol content (I42-144 mg/roo ml); then came the Javanese men (I64 mg/roo ml); and finally the Javanese women, who eat much more and have less physical exercise $(202 \mathrm{mg} / \mathrm{roO} \mathrm{ml})$. (In Europeans in Surinam, the content was $220 \mathrm{mg} / \mathrm{roo} \mathrm{ml}$.)

Finally, the prise was calculated of one gram of good protein in some important foods of Surinam.

For analysis in a number of Surinam foodstuffs, reference should be made to the detailed results of the writer's research trip, which were published in Tropical and geographical Medicine, 1960 and $196 \mathrm{I}$. 